\title{
Hepatitis B virus infection and active replication promote the formation of vascular invasion in hepatocellular carcinoma
}

\author{
Xubiao Wei ${ }^{\dagger}$, Nan Li ${ }^{\dagger}$, Shanshan Li, Jie Shi, Weixing Guo, Yaxin Zheng and Shuqun Cheng
}

\begin{abstract}
Background: Vascular invasion, including microvascular invasion (MVI) and portal vein tumor thrombus (PVTT), is associated with the postoperative recurrence of hepatocellular carcinoma (HCC). We aimed to investigate the potential impact of hepatitis B virus (HBV) activity on the development of vascular invasion.

Methods: Patients with HBV and tumor-related factors of HCC who had undergone hepatectomy were retrospectively enrolled and analyzed to identify the risk factors for developing vascular invasion.

Results: A total of 486 patients were included in this study. The overall proportion of patients with vascular invasion, including MVI and PVTT, was 60.3\% (293/486). The incidence of MVI was 58.2\% (283/486) whereas PVTT was 22.2\% (108/486). Univariate analysis revealed that positive Hepatitis B virus surface Antigen (HBsAg) was significantly associated with the presence of vascular invasion. In a multivariate regression analysis carried out in patients with HBV-related HCC, positive Hepatitis B virus e Antigen ( $\mathrm{HBeAg})(\mathrm{OR}=1.83, P=0.019)$ and a detectable seral HBV DNA load $(\mathrm{OR}=1.68, P=0.027)$ were independent risk factors of vascular invasion. The patients in the severe MVI group had a significantly higher rate of positive seral HBsAg $(P=0.005)$, positive seral HBeAg $(P=0.016)$, a detectable seral HBV DNA load $(>50 \mathrm{lU} / \mathrm{ml})(P<0.001)$ and a lower rate of anti-viral treatment $(P=0.002)$ compared with those in the mild MVI group and MVI-negative group. Whereas, HCC with PVTT invading the main trunk showed a significantly higher rate of positive $\mathrm{HBsAg}(P=0.007)$, positive $\mathrm{HBeAg}(P=0.04)$, cirrhosis $(P=0$. 005) and a lower rate of receiving antiviral treatment $(P=0.009)$ compared with patients with no PVTT or PVTT invading the ipsilateral portal vein. Patients with vascular invasion also had a significantly higher level of seral HBV DNA load than patients without vascular invasion $(P=0.008)$.
\end{abstract}

Conclusions: In HCC patients, HBV infection and active HBV replication were associated with the development of vascular invasion.

Keywords: Hepatitis B virus, Hepatocellular carcinoma, Vascular invasion, Anti-viral treatment, Postoperative recurrence

\footnotetext{
* Correspondence: chengshuqun@aliyun.com

${ }^{\dagger}$ Equal contributors

Department of Hepatic Surgery VI, Eastern Hepatobiliary Surgery Hospital,

Second Military Medical University, 225 Changhai Road, Yangpu District,

Shanghai 200438, China
} 


\section{Background}

Hepatocellular carcinoma (HCC) is the fifth most common cancer and the third leading cause of cancer-related death in the world [1]. Although surgical resection and liver transplantation could offer a promising prognosis for selected patients with $\mathrm{HCC}$, the high postoperative recurrence rate has impaired long-time survival. Among various risk factors, vascular invasion, including microvascular and macrovascular invasion, has been proven to be an independent factor predicting high recurrence and poor survival rate [2-4]. Microvascular invasion (MVI) was defined by most studies as microscopically confirmed tumor cell clusters within a vascular cavity lined with endothelium adjacent to the tumor $[5,6]$. Conversely, macrovascular invasion mostly occurs in the portal vein system and is known as a portal vein tumor thrombus (PVTT); a PVTT can be identified during imaging examination or intraoperative exploration. A large tumor size, multinodular lesion, elevated level of desc-carboxy prothrombin (DCP) and certain imaging characteristics were reported to be factors predicting the presence of MVI, whereas the tumor size, Edmondson-Steiner histological grading, number of nodules and $\alpha$-fetoprotein (AFP) level were associated with PVTT $[2,5,7,8]$.

Chronic hepatitis B virus (HBV) infection is a major risk factor for the development of liver cirrhosis and HCC, especially in East Asia [6]. HBV-related factors, such as seropositivity of hepatitis B e-antigen (HBeAg), high hepatitis B surface antigen (HBsAg) level and high serum HBV DNA load, were found to be significantly related to an increased risk of HBV-associated cirrhosis and HCC $[9,10]$. These factors were also reported to be associated with an increased recurrence rate and a decreased survival rate of HCC after surgical resection [11, 12]. Fundamental research has revealed that the HBV-initiated tumorigenic process may play a role in the development of the vascular invasion of HCC [13-15]. Recently, Lei Z et al. established a nomogram for preoperative prediction of the presence of MVI in HBV-related HCC, in which a high HBV DNA load $\left(>10^{4} \mathrm{IU} / \mathrm{ml}\right)$ was independently associated with the development of MVI [16]. These findings indicated a potential correlation between active HBV replication and the development of vascular invasion in HCC. To the best of our knowledge, no published study has provided insight into this issue. Therefore, we conducted a clinical study to further explore the impact of HBV-related factors on the formation of vascular invasion in HCC.

\section{Methods}

\section{Study population}

This was a retrospective study based on a prospectively compiled clinical and pathology database at a treatment center for HCC with PVTT at the Eastern Hepatobiliary Surgery Hospital, Shanghai, China. The study was approved by our Institutional Review Board, and written informed consent was obtained from all patients for their data to be used in this research.

$\mathrm{HCC}$ patients who had undergone surgical resection and confirmed by pathological examination at our center were included in this study. Exclusion criteria included hepatitis $\mathrm{C}$ virus ( $\mathrm{HCV}$ )-related $\mathrm{HCC}$, preoperative transarterial chemoembolization (TACE) or radiotherapy, non-curative resection, recurrent lesions, and a lack of complete clinical or pathological information.

For patients included in the study, the following clinical data and pathological results were collected: (1) demographic data, including age and gender and history of antiviral treatment; (2) results of preoperative laboratory blood tests, including HBsAg, HBeAg, HBV-DNA level, AFP, DCP, albumin, total bilirubin, alanine aminotransferase, and aspartate aminotransferase; and (3) imaging and pathologic findings, including the presence and classification of PVTT, maximal tumor size, tumor number, capsule, presence and classification of MVI, and presence of cirrhosis.

Tests for the viral replication status, including those for $\mathrm{HBsAg}$ and its antibody, $\mathrm{HBeAg}$ and its antibody, and $\mathrm{HBcAb}$, were performed. The serum HBV-DNA level was quantified by the polymerase chain reaction assay (ABI 7500; Applied Biosystems, Foster City, CA, USA) with a linear range of quantification of 50 to 2,000,000 IU/ml. The lower limit of detection was $50 \mathrm{IU} / \mathrm{ml}$. Patients who had received standard interferon therapy or had been using oral anti-viral drugs for a duration of more than 2 months before surgery were classified as the anti-viral treatment group.

\section{Diagnostic criteria of vascular invasion}

The diagnostic criterion of MVI was the presence of a tumor cell nest in the portal vein, hepatic artery, hepatic vein, bile duct or lymph duct in the tumor surrounding the liver tissue under microscopic examination [2, 17]. The number and distribution of invaded vessels were measured to divide the patients with MVI into two groups as follows: patients in the mild MVI group (M1) had 1 to 5 involved vessels distributed within a $1-\mathrm{cm}$ area from the tumor margin, whereas patients in the severe MVI group (M2) had more than 5 vessels invaded or had invaded vessels located more than $1 \mathrm{~cm}$ from the tumor margin. Every specimen was reviewed independently by two senior hepatobiliary pathologists to detect MVI. If the two pathologists had an inconsistent diagnosis, the findings were discussed to reach a final decision.

All HCC patients admitted to our center underwent a routine three-phrase dynamic CT or MRI examination before any treatment was carried out. PVTT was diagnosed when there were low-attenuation intraluminal masses that expanded the portal vein, or filling defects in the portal vein system, as presented in CT or MRI imaging. PVTT 
was confirmed and reassessed by palpation or ultrasound during operation. The final diagnosis was dependent on the intraoperative or pathologic findings. PVTT was classified according to Cheng's classification, which has been shown to be effective in stratifying the severity of PVTT as follows: type I, invasion of the tumor thrombus into the segmental or sectoral branches of the portal vein or above; type II, involvement of the right or left portal vein; type III, invasion of the main trunk of the portal vein; and type IV, involvement of the superior mesenteric vein.

\section{Statistical analysis}

All calculations were performed using Stata 12.0 software (StataCorp, Texas 77,845, USA). Continuous and categorized data were compared using Pearson's chi-squared test, Fisher's exact test, or Student's t test, as appropriate. Binary logistic regression was used to evaluate the relationship between the presence of vascular invasion as the dependent variable and factors that were significant in the univariate analysis as independent variables, using the stepwise backward method (Wald). The enter limit and remove limit were $P=0.05$ and $P=0.10$, respectively. Because viral factors, including seral $\mathrm{HbeAg}$, the seral HBV DNA load, presence of cirrhosis and usage of antiviral treatment, were only meaningful when patients had HBV infection, only patients with positive seral $\mathrm{HbsAg}$ were included in multivariate analysis. A $P<0.05$ was considered to indicate statistical significance.

\section{Results}

From May 1, 2015 to July 31, 2016, 675 patients with a preoperative diagnosis of $\mathrm{HCC}$ who underwent surgical resection at our center were identified. After careful examination, 189 patients were excluded, including 77 for preoperative TACE or radiotherapy, 36 for being diagnosed with a histological type other than HCC, 7 for HCV infection, 27 for recurrent lesions, 21 for non-curative resection, and 21 for failure to obtain detailed clinic information. Finally, 486 HCC patients, 422 men and 64 women, with a median age of 52 years (range, 22-80 years), fulfilled the inclusion criteria and were enrolled in the study.

Most patients (88.5\%, 430/486) had HBV-related HCC; the remaining 56 patients (11.5\%) had negative serum HBsAg. A total of 297 patients (61.1\%) had a detectable seral HBV DNA load (> $50 \mathrm{IU} / \mathrm{ml}$ ) in which 108 patients (22.2\%) had a high HBV DNA load level > $2000 \mathrm{IU} / \mathrm{ml}$. In total, 130 patients $(26.7 \%)$ were classified into the anti-viral treatment group (interferon, 7; lamivudine, 14 patients; lamivudine + adefovir dipivoxil, 7 patients; lamivudine + entecavir, 11 patients; adefovir dipivoxil, 26 patients; entecavir, 33 patients; entecavir + adefovir dipivoxil, 8 patients; others, 24 patients). The overall proportion of patients with vascular invasion, including MVI and PVTT, was $60.3 \%$ (293/486). The incidence of MVI was 58.2\% (283/486), whereas that of PVTT was $22.2 \%$ (108/486). A total of 98 patients (20.2\%) had both MVI and PVTT.

\section{Univariate analysis of viral and tumor factors predicting vascular invasion in HCC}

Univariate analysis revealed that virus-related serum markers, including positive $\mathrm{HBsAg}(P=0.005)$, positive HBeAg $(P<0.001)$ and a detectable HBV DNA load $(P<0.001)$, were significantly associated with the presence of vascular invasion, whereas vascular invasion was less frequently detected in patients in the anti-viral drug group $(P=0.003)$. The significant viral factors predicting MVI were the same as those of vascular invasion for patients with vascular invasion and MVI and were mostly overlapping. Similarly, virus-related seral markers, including positive HBsAg $(P=0.003)$, positive $\mathrm{HBeAg}(P=0.005)$, a detectable HBV DNA load $(P=0.025)$, and the presence of cirrhosis $(P<0.001)$, were significantly associated with the presence of PVTT, whereas patients who were undergoing anti-viral treatment $(P=0.015)$ had a significantly lower risk of developing PVTT (Table 1).

\section{Multivariate analysis of viral and tumor factors predicting vascular invasion in HCC}

Multivariate logistic regression analysis was carried out in patients with positive seral $\mathrm{HbsAg}$, utilizing binary variables that were significant in the univariate analysis. As shown in Table 2, positive seral HBeAg $(\mathrm{OR}=1.83, P=0.019)$ and a detectable seral HBV DNA load $(\mathrm{OR}=1.68, P=0.027)$ were independent risk factors of vascular invasion in the multivariate regression analysis. Moreover, tumor-related factors, including a seral AFP level $>20 \mathrm{ng} / \mathrm{ml}(\mathrm{OR}=2.51$, $P<0.001$ ), multiple lesions ( $\mathrm{OR}=2.18, P=0.038$ ), tumor size $>3 \mathrm{~cm}(\mathrm{OR}=1.73, P=0.035)$, Edmonson grades III/IV $(\mathrm{OR}=2.48, P=0.013)$ and incomplete/absent tumor capsule $(\mathrm{OR}=2.17, P=0.006)$, were significantly and independently associated with vascular invasion. Factors predictive of MVI were similar to those predictive of vascular invasion, except that the impact of seral HBeAg on the formation of MVI didn't reach statistical significance $(\mathrm{OR}=1.59, P=0.059)$. Regarding the risk factors of PVTT, the impact of the seropositivity of $\mathrm{HBeAg}(\mathrm{OR}=1.67$, $P=0.046)$, tumor diameter $>3 \mathrm{~cm}(\mathrm{OR}=8.86, P<0.001)$, incomplete or absent encapsulation $(\mathrm{OR}=3.59, P=0.003)$ and $\mathrm{DCP}>100 \mathrm{mAU} / \mathrm{ml}(\mathrm{OR}=2.90, P=0.022)$ were significant in the multivariable analysis.

\section{Correlation between the features of vascular invasion and HBV-related factors}

Table 3 shows that the severe MVI group had a significantly higher rate of positive seral $\mathrm{HBsAg}$, positive seral $\mathrm{HBeAg}$, a detectable seral HBV DNA load (> $50 \mathrm{IU} / \mathrm{ml}$ ), as well as a lower rate of antiviral treatment, compared with the mild MVI group and negative group. By 
Table 1 Univariate analysis of risk factors for formation of vascular invasion in hepatocellular carcinoma patients who underwent hepatectomy

\begin{tabular}{|c|c|c|c|c|c|c|c|c|c|}
\hline \multirow[t]{2}{*}{ Parameters } & \multicolumn{2}{|c|}{$\begin{array}{l}\text { Vascular } \\
\text { invasion }\end{array}$} & \multirow[t]{2}{*}{$P$} & \multicolumn{2}{|l|}{ MVI } & \multirow[t]{2}{*}{$P$} & \multicolumn{2}{|c|}{ PVTT } & \multirow[t]{2}{*}{$P$} \\
\hline & yes & no & & yes & no & & yes & $\overline{\text { no }}$ & \\
\hline \multicolumn{10}{|l|}{ Patient demographics } \\
\hline \multicolumn{10}{|l|}{ Age } \\
\hline$>50$ years & 153 & 125 & $0.006^{*}$ & 149 & 129 & $0.017^{*}$ & 53 & 225 & 0.053 \\
\hline$<=50$ years & 140 & 68 & & 134 & 74 & & 55 & 153 & \\
\hline \multicolumn{10}{|l|}{ Gender } \\
\hline Male & 255 & 167 & 0.873 & 245 & 177 & 0.842 & 99 & 323 & 0.092 \\
\hline Female & 38 & 26 & & 38 & 26 & & 9 & 55 & \\
\hline \multicolumn{10}{|l|}{$\begin{array}{l}\text { Preoperative } \\
\text { laboratory test }\end{array}$} \\
\hline \multicolumn{10}{|l|}{ Total bilirubin } \\
\hline$>20 \mu \mathrm{mol} / \mathrm{l}$ & 48 & 32 & 0.954 & 48 & 32 & 0.725 & 16 & 64 & 0.601 \\
\hline$<=20 \mathrm{umol} / \mathrm{l}$ & 245 & 161 & & 235 & 171 & & 92 & 314 & \\
\hline \multicolumn{10}{|l|}{ ALT } \\
\hline$>42 \mathrm{U} / \mathrm{l}$ & 128 & 83 & 0.882 & 122 & 89 & 0.872 & 49 & 162 & 0.642 \\
\hline$<=42 \mathrm{U} / \mathrm{l}$ & 165 & 110 & & 161 & 114 & & 59 & 216 & \\
\hline \multicolumn{10}{|l|}{ AST, } \\
\hline$>37 \mathrm{U} / \mathrm{l}$ & 157 & 114 & 0.234 & 152 & 119 & 0.282 & 62 & 209 & 0.696 \\
\hline$<=37 \mathrm{U} / \mathrm{l}$ & 136 & 79 & & 131 & 84 & & 46 & 169 & \\
\hline \multicolumn{10}{|l|}{ Albumin } \\
\hline$>40 \mathrm{~g} / \mathrm{l}$ & 193 & 100 & 0.734 & 188 & 135 & 0.987 & 67 & 256 & 0.270 \\
\hline$<=40 \mathrm{~g} / \mathrm{l}$ & 130 & 63 & & 95 & 68 & & 41 & 122 & \\
\hline \multicolumn{10}{|l|}{ DCP } \\
\hline$>100 \mathrm{mAU} / \mathrm{ml}$ & 250 & 147 & $0.011^{*}$ & 241 & 156 & $0.019^{*}$ & 102 & 295 & $<0.001^{*}$ \\
\hline$<=100 \mathrm{mAU} / \mathrm{ml}$ & 43 & 46 & & 42 & 47 & & 6 & 83 & \\
\hline \multicolumn{10}{|l|}{ Alpha-fetoprotein } \\
\hline$>20 \mathrm{ng} / \mathrm{ml}$ & 226 & 102 & $<0.001^{*}$ & 219 & 109 & $<0.001^{*}$ & 85 & 243 & $0.005^{*}$ \\
\hline$<=20 \mathrm{ng} / \mathrm{ml}$ & 67 & 91 & & 64 & 94 & & 23 & 135 & \\
\hline \multicolumn{10}{|l|}{ Tumor characteristics } \\
\hline \multicolumn{10}{|l|}{ Diameter } \\
\hline$>3 \mathrm{~cm}$ & 247 & 138 & $0.001^{*}$ & 238 & 147 & $0.002^{*}$ & 105 & 280 & $<0.001^{*}$ \\
\hline$<=3 \mathrm{~cm}$ & 46 & 55 & & 45 & 56 & & 3 & 98 & \\
\hline \multicolumn{10}{|l|}{ Number of lesions } \\
\hline Multiple & 43 & 15 & $0.022^{*}$ & 41 & 17 & $0.040^{*}$ & 20 & 38 & $0.017^{*}$ \\
\hline Single & 250 & 178 & & 242 & 186 & & 88 & 340 & \\
\hline \multicolumn{10}{|l|}{ Encapsulation } \\
\hline $\begin{array}{l}\text { Incomplete/ } \\
\text { absent }\end{array}$ & 259 & 145 & $<0.001^{*}$ & 250 & 154 & $<0.001^{*}$ & 101 & 303 & $0.001^{*}$ \\
\hline Complete & 34 & 48 & & 33 & 49 & & 7 & 75 & \\
\hline \multicolumn{10}{|l|}{ Edmonson grading } \\
\hline Grades III/IV & 277 & 151 & $<0.001^{*}$ & 267 & 161 & $<0.001^{*}$ & 101 & 327 & $0.047^{*}$ \\
\hline Grades I/II & 16 & 42 & & 16 & 42 & & 7 & 51 & \\
\hline Virus-related factors & & & & & & & & & \\
\hline Seral HBsAg & & & & & & & & & \\
\hline Positive & 269 & 161 & $0.005^{*}$ & 260 & 170 & $0.006^{*}$ & 104 & 326 & $0.003^{*}$ \\
\hline Negative & 24 & 32 & & 23 & 33 & & 4 & 52 & \\
\hline
\end{tabular}

Table 1 Univariate analysis of risk factors for formation of vascular invasion in hepatocellular carcinoma patients who underwent hepatectomy (Continued)

\begin{tabular}{|c|c|c|c|c|c|c|c|c|c|}
\hline \multicolumn{10}{|l|}{ Seral HBeAg } \\
\hline Positive & 93 & 32 & $<0.001^{*}$ & 88 & 37 & $0.002^{*}$ & 39 & 86 & $0.005^{*}$ \\
\hline Negative & 200 & 160 & & 195 & 165 & & 69 & 291 & \\
\hline \multicolumn{10}{|l|}{ HBV DNA load } \\
\hline $\begin{array}{l}\text { Detectable } \\
(>50 \mathrm{IU} / \mathrm{ml})\end{array}$ & 203 & 94 & $<0.001^{*}$ & 197 & 100 & $<0.001^{*}$ & 76 & 221 & $0.025^{*}$ \\
\hline $\begin{array}{l}\text { Undetectable } \\
(<=50 \mathrm{IU} / \mathrm{ml})\end{array}$ & 90 & 99 & & 86 & 103 & & 32 & 157 & \\
\hline High (> $2000 \mathrm{IU} / \mathrm{ml}$ ) & 110 & 62 & 0.222 & 106 & 66 & 0.261 & 39 & 133 & 0.859 \\
\hline $\operatorname{Low}(<=2000 \mathrm{IU} / \mathrm{ml})$ & 183 & 131 & & 177 & 137 & & 69 & 39 & \\
\hline \multicolumn{10}{|l|}{ Presence of cirrhosis } \\
\hline Yes & 101 & 52 & 0.08 & 96 & 57 & 0.171 & 49 & 104 & $<0.001^{*}$ \\
\hline No & 192 & 141 & & 187 & 146 & & 59 & 274 & \\
\hline \multicolumn{10}{|l|}{ Anti-virus treatment } \\
\hline Yes & 64 & 66 & $0.003^{*}$ & 63 & 67 & $0.008^{*}$ & 19 & 111 & $0.015^{*}$ \\
\hline No & 229 & 127 & & 220 & 136 & & 89 & 267 & \\
\hline
\end{tabular}

MVI Microvascular invasion; PVTT Portal vein tumor thrombus; ALT Alanine aminotransferase; AST Aspartate aminotransferase; DCP Des-gamma-carboxy prothrombin; $H B s A g$ Hepatitis B virus s Antigen; $H B e A g$ Hepatitis B virus e Antigen; $H B V$ Hepatitis B virus

$* P<0.05$

contrast, for the classification of PVTT, HCC with type III/IV PVTT had a significantly higher rate of positive seral HBsAg, positive seral HBeAg, and cirrhosis, as well as a lower rate of receiving antiviral treatment compared with the type I/II group and PVTT-negative group. Patients with vascular invasion had a significantly higher seral HBV DNA load than patients without vascular invasion (Table 4).

\section{Discussion}

The presence of vascular invasion, including MVI and PVTT, was significantly associated with a high risk of postoperative recurrence, which is a major obstacle to improving the prognosis of HCC $[6,17,18]$. However, the risk factors and underlying mechanism leading to the formation of vascular invasion remain largely unknown. In East Asia, the majority of HCC develops within an environment of chronic inflammation caused by HBV infection. Recently, the results of fundamental studies have indicated that the HBV status is a potent etiological factor predisposing HCC patients to develop vascular invasion. $\mathrm{HBV} \mathrm{X}$ protein $(\mathrm{HBx})$, a key regulatory multifunctional protein of the virus, has been reported to be involved in the development of MVI and is associated with postoperative recurrence $[14,19,20]$. Yang et al. found that the seropositivity of HBsAg was associated with a high risk of developing PVTT, and the activity of the TGF- $\beta$-miR-34a-CCL22 axis induced by the change in the liver microenvironment caused by HBV infection may play an important role in the 
Table 2 Multivariate logistic regression analysis of factors predictive of vascular invasion in patients with positive seral $\mathrm{HbsAg}$

\begin{tabular}{|c|c|c|c|}
\hline Variables & $\begin{array}{l}\text { Odds } \\
\text { ratio }\end{array}$ & $95 \% \mathrm{Cl}$ & $P$ value \\
\hline \multicolumn{4}{|l|}{ Risk of vascular invasion } \\
\hline Age ( $>50$ years vs $<=50$ years) & 0.68 & $0.44-1.04$ & 0.078 \\
\hline $\begin{array}{l}\text { Alpha-fetoprotein } \\
(>20 \mathrm{ng} / \mathrm{ml} \text { vs }<=20 \mathrm{ng} / \mathrm{ml})\end{array}$ & 2.51 & $1.59-3.96$ & $<0.01^{*}$ \\
\hline $\begin{array}{l}\text { Tumor number } \\
\text { (Multiple vs Single) }\end{array}$ & 2.18 & $1.04-4.55$ & $0.038^{*}$ \\
\hline Diameter $(>3 \mathrm{~cm}$ vs $<=3 \mathrm{~cm}$ ) & 1.73 & $1.04-2.88$ & $0.035^{*}$ \\
\hline $\begin{array}{l}\text { Edmonson grading } \\
\text { (Grades III/IV vs Grades I/II) }\end{array}$ & 2.48 & $1.21-5.05$ & $0.013^{*}$ \\
\hline $\begin{array}{l}\text { Tumor capsule } \\
\text { (Incomplete/absent vs Complete) }\end{array}$ & 2.17 & $1.25-3.77$ & $0.006^{*}$ \\
\hline Seral HBeAg (Positive vs Negative) & 1.83 & $1.10-3.03$ & $0.019^{*}$ \\
\hline $\begin{array}{l}\text { Seral HBV DNA load } \\
(>50 \mathrm{IU} / \mathrm{ml} \text { vs }<=50 \mathrm{IU} / \mathrm{ml})\end{array}$ & 1.68 & $1.06-2.65$ & $0.027^{*}$ \\
\hline \multicolumn{4}{|l|}{ Risk of microscopic vascular invasion } \\
\hline $\begin{array}{l}\text { Alpha-fetoprotein } \\
\text { (> } 20 \mathrm{ng} / \mathrm{ml} \text { vs }<=20 \mathrm{ng} / \mathrm{ml} \text { ) }\end{array}$ & 2.59 & $1.65-4.05$ & $<0.01^{*}$ \\
\hline Tumor number (Multiple vs Single) & 2.21 & $1.09-4.51$ & $0.028^{*}$ \\
\hline Diameter (>3 cm vs < = $3 \mathrm{~cm}$ ) & 1.58 & $0.96-2.61$ & 0.074 \\
\hline $\begin{array}{l}\text { Edmonson grading } \\
\text { (Grades III/IV vs Grades I/II) }\end{array}$ & 2.24 & $1.11-4.54$ & $0.024^{*}$ \\
\hline $\begin{array}{l}\text { Tumor capsule } \\
\text { (Incomplete/absent vs Complete) }\end{array}$ & 2.04 & $1.18-3.51$ & $0.011^{*}$ \\
\hline Seral HBeAg (Positive vs Negative) & 1.59 & $0.98-2.57$ & 0.059 \\
\hline $\begin{array}{l}\text { Seral HBV DNA load } \\
(>50 \mathrm{IU} / \mathrm{ml} \mathrm{vs}<=50 \mathrm{IU} / \mathrm{ml})\end{array}$ & 1.76 & $1.12-2.76$ & $0.013^{*}$ \\
\hline \multicolumn{4}{|l|}{ Risk of portal vein tumor thrombus } \\
\hline $\begin{array}{l}\mathrm{DCP}(>100 \mathrm{mAU} / \mathrm{ml} \mathrm{vs} \\
<=100 \mathrm{mAU} / \mathrm{ml})\end{array}$ & 2.90 & $1.17-7.12$ & $0.022^{*}$ \\
\hline Tumor diameter ( $>3 \mathrm{~cm}$ vs $<=3 \mathrm{~cm}$ ) & 8.86 & $2.67-29.39$ & $<0.01^{*}$ \\
\hline $\begin{array}{l}\text { Tumor capsule (Incomplete/ } \\
\text { absence vs Complete) }\end{array}$ & 3.59 & $1.56-8.25$ & $0.003^{*}$ \\
\hline Seral HBeAg (Positive vs Negative) & 1.67 & $1.01-2.75$ & $0.046^{*}$ \\
\hline Anti-virus treatment (Yes vs No) & 0.59 & $0.33-1.05$ & 0.075 \\
\hline
\end{tabular}

Cl Confidential Interval; HBeAg Hepatitis B virus e Antigen; HBV Hepatitis B virus; $D C P$ Des-gamma-carboxy prothrombin; $H B s A g$ Hepatitis $B$ virus s Antigen; HBeAg Hepatitis B virus e Antigen

${ }^{*} P<0.05$

development of PVTT [15]. The potential correlation between HBV replication and the formation of MVI in HCC have also been studied in some preliminary clinical studies. Chen et al. retrospectively studied the impact of ascites, as well as tumor- and HBV-related factors, on the formation of vascular invasion and found negative results concerning the impact of viral factors; however, it is worth noting that the limited number of cases with MVI $(n=12)$ and incomplete data concerning the status of $\mathrm{HBV}$ infection may limit the power of their results
[21]. To establish a preoperative prediction model for MVI, a large cohort of HBV-related HCC patients $(n=1004)$ was analyzed by Lei et al., revealing that a high seral HBV DNA load (> $\left.10^{4} \mathrm{IU} / \mathrm{ml}\right)$ was an independent factor predicting the presence of MVI. The other predictive variables were well-known tumorrelated factors, including a large tumor diameter, multiple nodules, an incomplete capsule and an AFP level > $20 \mathrm{ng} / \mathrm{ml}$ [16]. Nevertheless, the relationship between $\mathrm{HBV}$ infection and vascular invasion has rarely been intentionally researched in a well-designed clinical study.

Our study was based on a prospectively collected database with comprehensive data indicating the status of HBV infection and vascular invasion. The results showed that compared with patients without $\mathrm{HBV}$ infection, the incidence of vascular invasion, including MVI and PVTT, was significantly increased in HBV-related HCC. In the multivariate analysis carried out in positive HBsAg patients, positive $\mathrm{HBeAg}$ and a detectable seral HBV DNA load (> $50 \mathrm{IU} / \mathrm{ml}$ ) were significantly associated with development of vascular invasion. In addition, our results revealed that in HBV-related HCC patients, a more severe level of vascular invasion was associated with a higher rate of active HBV replication, as reflected in positive $\mathrm{HBeAg}$ or a detectable HBV DNA load. These findings provided promising clinical evidence to demonstrate that in addition to tumor-related factors, the activity of HBV infection plays a key role in the development of vascular invasion in HCC patients.

The postoperative recurrence of $\mathrm{HBV}$-related $\mathrm{HCC}$ was categorized into two groups, early and late recurrence, with a cut-off time at 2 years [22]. Late recurrence ( $>2$ years after resection) usually presented as a metachronous tumor with different genetic and histological features from the primary $\mathrm{HCC}[22,23]$. It was revealed that HBV-related factors, including a high hepatic inflammatory activity score and high HBV DNA load, were significantly associated with late recurrence, whereas sustained suppression of HBV replication by anti-viral drugs achieved a lower rate of late recurrence [12, 24, 25]. Tumors occurring within 2 years after surgery were classified as early recurrence, which was strongly associated with tumor-related factors, including tumor size and the presence of nodules, vascular invasion and resection margin [22]. A randomized controlled trial by Lin et al. revealed that patients receiving anti-viral treatment showed a significantly better 2-year overall (93.8\% vs $62.2 \%)$ and recurrence-free (55.6\% vs $19.5 \%)$ survival [26]. However, it is difficult to understand the effect of anti-viral drugs on inhibiting early postoperative recurrence ( $<2$ years after resection), which was considered the result of the regrowth of micro-metastases in the liver that were not detected and resected during the 
Table 3 Correlations between the severity of microvascular invasion or portal vein tumor thrombus and viral features in hepatocellular carcinoma ${ }^{a}$

\begin{tabular}{|c|c|c|c|c|c|c|c|c|}
\hline \multirow{2}{*}{$\begin{array}{l}\text { HBV-related } \\
\text { factors }\end{array}$} & \multicolumn{3}{|c|}{ Severity of MVI } & \multirow[t]{2}{*}{$P$} & \multicolumn{3}{|c|}{ Classification of PVTT } & \multirow[t]{2}{*}{$P$} \\
\hline & None (\%) & Mild (\%) & Severe (\%) & & None (\%) & I/II (\%) & III/IV (\%) & \\
\hline \multicolumn{9}{|l|}{ Seral HBsAg } \\
\hline Positive & $171(83.8)$ & $127(89.4)$ & $131(94.9)$ & $0.005^{*}$ & $326(86.2)$ & $74(94.9)$ & $30(100)$ & $0.007^{*}$ \\
\hline Negative & $33(16.2)$ & 15 (10.6) & $7(5.1)$ & & $52(13.8)$ & $4(5.1)$ & $0(0)$ & \\
\hline \multicolumn{9}{|l|}{ Seral HBeAg } \\
\hline Positive & 37 (21.6) & $38(29.9)$ & $48(36.6)$ & $0.016^{*}$ & $84(25.8)$ & $30(40.5)$ & $9(30)$ & $0.04^{*}$ \\
\hline Negative & $134(78.4)$ & $89(60.1)$ & $83(63.4)$ & & $242(74.2)$ & $44(59.5)$ & $21(70)$ & \\
\hline \multicolumn{9}{|c|}{ Seral HBV DNA load } \\
\hline$>50 \mathrm{IU} / \mathrm{ml}$ & 99 (57.9) & $90(70.9)$ & $106(80.9)$ & $<0.001^{*}$ & $219(67.2)$ & $52(70.3)$ & $24(80)$ & 0.355 \\
\hline$<=50 \mathrm{IU} / \mathrm{ml})$ & $72(42.1)$ & $37(29.1)$ & $25(19.1)$ & & $107(32.8)$ & $22(29.7)$ & $6(20)$ & \\
\hline \multicolumn{9}{|c|}{ Presence of cirrhosis } \\
\hline Yes & $52(30.4)$ & $48(37.8)$ & $44(33.6)$ & 0.418 & $96(29.4)$ & $32(43.2)$ & $16(53.3)$ & $0.005^{*}$ \\
\hline No & 119 (69.6) & $79(62.2)$ & $87(66.4)$ & & $230(60.6)$ & $42(56.8)$ & $14(46.7)$ & \\
\hline \multicolumn{9}{|l|}{ Antivirus treatment } \\
\hline Yes & 66 (38.6) & $36(28.3)$ & $26(19.8)$ & $0.002^{*}$ & $109(33.4)$ & $15(20.3)$ & $4(13.3)$ & $0.009^{*}$ \\
\hline No & $105(61.4)$ & $91(61.7)$ & $105(80.2)$ & & $217(66.6)$ & $59(79.7)$ & $26(86.7)$ & \\
\hline
\end{tabular}

HBV Hepatitis B virus; $H B s A g$ Hepatitis B virus s Antigen; HBeAg Hepatitis B virus e Antigen a analysis was only carried out in patients with positive $\mathrm{HBsAg}$ except the "HBsAg" row ${ }^{*} P<0.05$

operation. Our result demonstrates that active HBV replication is associated with a high rate of vascular invasion in HCC patients, which may partially explain the anti-tumor effect of antiviral treatment. We could speculate that the suppression of HBV replication via antiviral treatment might decrease the invasiveness and metastatic potential of HCC to reduce the risk of early postoperative recurrence.

The seral HBV DNA load is usually divided into high and low levels at a cut-off value of $2000 \mathrm{IU} / \mathrm{ml}$. In this study, the impact of the seral HBV DNA load on the

Table 4 Difference in the seral HBV DNA load between HBV-related hepatocellular carcinoma patients with or without vascular invasion ${ }^{a}$

\begin{tabular}{llc}
\hline Variable & $\begin{array}{l}\text { HBV DNA load, log } 10 \mathrm{IU} / \mathrm{ml} \\
\text { (mean } \pm \text { SD) }\end{array}$ & $P$ \\
\hline Vascular invasion & & \\
Yes & $3.28 \pm 0.14$ & $0.008^{*}$ \\
No & $2.64 \pm 0.20$ & \\
Microvascular invasion & & $0.008^{*}$ \\
Yes & $3.29 \pm 0.14$ & \\
No & $2.66 \pm 0.19$ & \\
Portal vein tumor thrombus & 0.694 \\
Yes & $3.13 \pm 0.22$ & \\
No & $3.02 \pm 0.14$ & \\
\hline
\end{tabular}

HBV Hepatitis B virus; SD Standard Deviation

a analysis was only carried out in patients with positive $\mathrm{HBsAg}$

${ }^{*} P<0.05$ formation of vascular invasion was not significant if the cut-off value was set at this point. This result implies that the correlation between the HBV DNA load and occurrence of vascular invasion is not linear. Additionally, this result may also be caused by a proportion of patients with a high HBV DNA load being in the "immune tolerant" phase with no or mild substantial liver injury [10]. According to the current guidelines, anti-viral drugs should be prescribed in chronic hepatitis B patients with a serum HBV DNA load above $2000 \mathrm{IU} / \mathrm{ml}$ and elevated ALT levels, in the absence of sufficient evidence of cirrhosis [10]. However, for patients with a low HBV DNA level (< $2000 \mathrm{IU} / \mathrm{ml}$ ) without advanced liver disease, the benefit of anti-viral treatment has not been well clarified. In this study, HCC patients with an undetectable HBV DNA load $(\leq 50 \mathrm{IU} / \mathrm{ml})$ had a lower incidence of vascular invasion than patients with a detectable HBV DNA load (> $50 \mathrm{IU} /$ $\mathrm{ml})$. These results suggested that it may also be beneficial to receive anti-viral drugs for patients who do not meet the current treatment indication.

The suppressed HBV replication by anti-viral treatment was supposed to correlate with a lower rate of vascular invasion. However, the inhibitory effect of antiviral treatment on the development of vascular invasion was overshadowed by tumor-related factors in the multivariate analysis. The following reasons may explain this phenomenon. First, patients who have undergone antiviral treatment usually have no or mild cirrhosis with normal liver function $[27,28]$. Surgeons are more likely 
to apply hepatectomy with a wider resection margin to these patients. Theoretically, a wide surgical margin will lead to a higher detection rate of MVI during pathological evaluation. Second, patients who have undergone anti-viral treatment have enjoyed good health care and regular surveillance, leading to early detection of HCC. Thus, the inhibitory effect of anti-viral treatment tended to be overshadowed by the early tumor features.

It is worth noting that MVI and PVTT have different risk factor profiles in our research. For HBV-related factors, only detectable HBV load was associated MVI, while only positive HBeAg was associated with PVTT. Although MVI and PVTT were two common types of vascular invasion of $\mathrm{HCC}$, there was no evidence indicating potential causal relationship between them. Previous clinic studies also revealed that MVI and PVTT had inconsistent predicting factors [2, $5,7,8]$. Further fundamental and clinic studies are needed to clarify the relationship between MVI and PVTT.

This study might not be able to reveal the full landscape of the relationship between HBV activity and the occurrence of vascular invasion in HCC. In particular, because of the limited follow-up time, we failed to carry out a survival analysis to determine significant factors contributing to recurrence or survival. However, the main finding of this study is the association between HBV infection status and presence of vascular invasion in HCC, lack of survival information may have a less impact on our conclusion. Additionally, inconsistency existed between the protocol of anti-viral treatment and surgical procedures because of the retrospective nature of this research. Furthermore, the surgical margin varied in patients with different levels of cirrhosis, a finding that might affect the detection rate of MVI. At last, only HBV-related HCC was studied in this research, the conclusion isn't applicable for HCC caused by other hepatic virus. Despite these limitations, we first found the interesting phenomenon that HBV infection and replication status were independently associated with the formation of vascular invasion in HCC, which may partially explain the inhibitory effect of anti-viral treatment on early $\mathrm{HCC}$ recurrence.

\section{Conclusions}

In addition to characteristics of the tumor itself, HBV infection and active replication were independently associated with the development of vascular invasion in HCC. In patients with HBV-related HCC with positive $\mathrm{HBeAg}$ or a detectable HBV DNA load, an increased risk of vascular invasion should be recognized.

\section{Abbreviations}

AFP: a-fetoprotein; DCP: Desc-carboxy Prothrombin; HBeAg: Hepatitis B e-antigen; HBsAg: Hepatitis B surface-antigen; HBV: Hepatitis B Virus; HBX: HBV X Protein; HCC: Hepatocellular Carcinoma; HCV: Hepatitis C Virus; MVI: Microvascular Invasion; PVTT: Portal Vein Tumor Thrombus; TACE: Transarterial Chemoembolization

\section{Acknowledgement}

Not applicable.

\section{Funding}

Study design: The National Key Basic Research Program "973

project"(2015CB554000); Shanghai Shenkang Project (SHDC12015106).

Data collection and analysis: the Science Fund for Creative Research Groups (81521091).

Shanghai Science and Technology Committee (134119a0200);

Manuscript drafting and revision: 2012 SMMU Innovation Alliance for Liver Cancer Diagnosis and Treatment; Collaborative Innovation Center for Cancer Medicine.

\section{Availability of data and materials}

The datasets generated and analyzed during the current study are not publicly available because further fundamental and clinical research will be carried out based on this cohort; however, they are available from the corresponding author upon reasonable request.

\section{Authors' contributions}

XBW and NLi: contributed equally to this article. collected and analyzed data, drafted and revised the manuscript. SSL: collected and analyzed data. JS, WXG and YXZ: collected data, revised the manuscript. SQC: designed the study, collected data, revised the manuscript. All authors read and approved the final manuscript.

Competing interests

The authors declare that they have no competing interests.

Consent for publication

Not applicable.

Ethics approval and consent to participate

The study was approved by the Institutional Review Board of Eastern Hepatobiliary Surgery Hospital, and written informed consent was obtained from all patients for their data to be used in this research.

\section{Publisher's Note}

Springer Nature remains neutral with regard to jurisdictional claims in published maps and institutional affiliations.

Received: 20 January 2017 Accepted: 24 April 2017

Published online: 02 May 2017

References

1. McGlynn KA, London WT. The global epidemiology of hepatocellular carcinoma: present and future. Clin Liver Dis. 2011;15(2):223-43. vii-x

2. Rodriguez-Peralvarez M, Luong TV, Andreana L, Meyer T, Dhillon AP, Burroughs AK. A systematic review of microvascular invasion in hepatocellular carcinoma: diagnostic and prognostic variability. Ann Surg Oncol. 2013;20(1):325-39.

3. Llovet JM, Bustamante J, Castells A, Vilana R, Ayuso Mdel C, Sala M, Bru C, Rodes J, Bruix J. Natural history of untreated nonsurgical hepatocellular carcinoma: rationale for the design and evaluation of therapeutic trials. Hepatology. 1999:29(1):62-7.

4. Shi J, Lai EC, Li N, Guo WX, Xue J, Lau WY, Wu MC, Cheng SQ. Surgica treatment of hepatocellular carcinoma with portal vein tumor thrombus. Ann Surg Oncol. 2010;17(8):2073-80.

5. Fujita N, Aishima S, Iguchi T, Mano Y, Taketomi A, Shirabe K, Honda H, Tsuneyoshi M, Oda Y. Histologic classification of microscopic portal venous invasion to predict prognosis in hepatocellular carcinoma. Hum Pathol. 2011;42(10):1531-8.

6. Iguchi T, Shirabe K, Aishima S, Wang H, Fujita N, Ninomiya M, Yamashita Y, Ikegami T, Uchiyama H, Yoshizumi T, et al. New pathologic stratification of microvascular invasion in hepatocellular carcinoma: predicting prognosis after living-donor liver transplantation. Transplantation. 2015;99(6):1236-42.

7. Zhou L, Rui JA, Wang SB, Chen SG, Qu Q. Risk factors of microvascular invasion, portal vein tumor thrombosis and poor post-resectional survival in HBV-related hepatocellular carcinoma. Hepato-Gastroenterology. 2014; 61(134):1696-703

8. Shirabe K, Toshima T, Kimura K, Yamashita Y, Ikeda T, Ikegami T, Yoshizumi T, Abe K, Aishima S, Maehara Y. New scoring system for prediction of 
microvascular invasion in patients with hepatocellular carcinoma. Liver international : official journal of the International Association for the Study of the Liver. 2014;34(6):937-41.

9. Qu LS, Zhang HF. Significance of viral status on prognosis of hepatitis B-related hepatocellular carcinoma after curative resection in East Asia. Hepatology research : the official journal of the Japan Society of Hepatology. 2015;

10. European Association For The Study Of The L. EASL clinical practice guidelines: management of chronic hepatitis B virus infection. J Hepatol. 2012;57(1):167-85.

11. Yu LH, Li N, Shi J, Guo WX, Wu MC, Cheng SQ. Does anti-HBV therapy benefit the prognosis of HBV-related hepatocellular carcinoma following hepatectomy? Ann Surg Oncol. 2014;21(3):1010-5.

12. Wu CY, Chen YJ, Ho HJ, Hsu YC, Kuo KN, Wu MS, Lin JT. Association between nucleoside analogues and risk of hepatitis B virus-related hepatocellular carcinoma recurrence following liver resection. JAMA. 2012;308(18):1906-14.

13. B. H, G. F, L. R, C. D, M. S, J. C, P. B-S, R. H, M.-A. B, D. S et al: hepatocellular carcinoma replicating hepatitis $B$ virus: a clinical, virological and transcriptional entity. Hepatology 2014, 60(SUPPL 1):995A-996A.

14. Chen L, Zhang Q, Chang W, Du Y, Zhang H, Cao G. Viral and host inflammation-related factors that can predict the prognosis of hepatocellular carcinoma. Eur J Cancer. 2012;48(13):1977-87.

15. Yang $P$, Li QJ, Feng Y, Zhang Y, Markowitz GJ, Ning S, Deng Y, Zhao J, Jiang S, Yuan Y, et al. TGF-beta-miR-34a-CCL22 signaling-induced Treg cell recruitment promotes venous metastases of HBV-positive hepatocellular carcinoma. Cancer Cell. 2012;22(3):291-303.

16. Lei Z, Li J, Wu D, Xia Y, Wang Q, Si A, Wang K, Wan X, Lau WY, Wu M, et al. Nomogram for preoperative estimation of microvascular invasion risk in hepatitis B virus-related hepatocellular carcinoma within the Milan criteria. JAMA surgery. 2015:1-8.

17. Sumie S, Nakashima O, Okuda K, Kuromatsu R, Kawaguchi A, Nakano M, Satani M, Yamada S, Okamura S, Hori M, et al. The significance of classifying microvascular invasion in patients with hepatocellular carcinoma. Ann Surg Oncol. 2014:21(3):1002-9.

18. Chen JS, Wang Q, Chen XL, Huang XH, Liang LJ, Lei J, Huang JQ, Li DM, Cheng ZX. Clinicopathologic characteristics and surgical outcomes of hepatocellular carcinoma with portal vein tumor thrombosis. J Surg Res. 2012;175(2):243-50.

19. Ryu SH, Chung YH, Lee H, Kim JA, Shin HD, Min HJ, Seo DD, Jang MK, Yu E, Kim KW. Metastatic tumor antigen 1 is closely associated with frequent postoperative recurrence and poor survival in patients with hepatocellular carcinoma. Hepatology. 2008;47(3):929-36.

20. Xu J, Liu H, Chen L, Wang S, Zhou L, Yun X, Sun L, Wen Y, Gu J. Hepatitis B virus $X$ protein confers resistance of hepatoma cells to anoikis by up-regulating and activating p21-activated kinase 1. Gastroenterology. 2012;143(1):199-212. e194

21. Chen C, Chen DP, Gu YY, Hu LH, Wang D, Lin JH, Li ZS, Xu J, Wang G. Vascular invasion in hepatitis B virus-related hepatocellular carcinoma with underlying cirrhosis: possible associations with ascites and hepatitis B viral factors? Tumour Biol. 2015;36(8):6255-63.

22. Wu JC, Huang YH, Chau GY, Su CW, Lai CR, Lee PC, Huo TI, Sheen IJ, Lee SD, Lui WY. Risk factors for early and late recurrence in hepatitis B-related hepatocellular carcinoma. J Hepatol. 2009;51(5):890-7.

23. Kim WR, Gores GJ. Recurrent hepatocellular carcinoma: it's the virus! J Clin Oncol. 2013;31(29):3621-2.

24. Kim BK, Park JY, Kim do Y, Kim JK, Kim KS, Choi JS, Moon BS, Han KH, Chon $C Y$, Moon YM et al: Persistent hepatitis B viral replication affects recurrence of hepatocellular carcinoma after curative resection. Liver international : official journal of the International Association for the Study of the Liver 2008, 28(3):393-401.

25. Huang G, Lai EC, Lau WY, Zhou WP, Shen F, Pan ZY, Fu SY, Wu MC. Posthepatectomy HBV reactivation in hepatitis B-related hepatocellular carcinoma influences postoperative survival in patients with preoperative low HBV-DNA levels. Ann Surg. 2013;257(3):490-505.

26. Yin J, Li N, Han Y, Xue J, Deng Y, Shi J, Guo W, Zhang H, Wang H, Cheng S, et al. Effect of antiviral treatment with nucleotide/nucleoside analogs on postoperative prognosis of hepatitis B virus-related hepatocellular carcinoma: a two-stage longitudinal clinical study. J Clin Oncol. 2013;31(29):3647-55.

27. Li N, Lai EC, Shi J, Guo WX, Xue J, Huang B, Lau WY, Wu MC, Cheng SQ. A comparative study of antiviral therapy after resection of hepatocellular carcinoma in the immune-active phase of hepatitis B virus infection. Ann Surg Oncol. 2010;17(1):179-85.

28. Yu LH, Li N, Cheng SQ: the role of antiviral therapy for HBV-related hepatocellular carcinoma. Int J Hepatol 2011, 2011:416459.

\section{Submit your next manuscript to BioMed Central and we will help you at every step:}

- We accept pre-submission inquiries

- Our selector tool helps you to find the most relevant journal

- We provide round the clock customer support

- Convenient online submission

- Thorough peer review

- Inclusion in PubMed and all major indexing services

- Maximum visibility for your research

Submit your manuscript at www.biomedcentral.com/submit
Biomed Central 